Check for updates

The BMJ

Cite this as: BMJ2021;372:n511 http://dx.doi.org/10.1136/bmi.n511 Published: 19 February 2021

\title{
Covid-19: Hancock's failure to publish contracts was unlawful
}

\section{Clare Dyer}

The UK government acted unlawfully in failing to publish details of dozens of contracts awarded without competition for goods and services such as personal protective equipment (PPE) needed during the covid-19 pandemic, a High Court judge has ruled. ${ }^{1}$

Mr Justice Chamberlain upheld a challenge by the non-profit Good Law Project to the failure by Matt Hancock, health and social care secretary for England, to publish notices for a "substantial" number of the deals, as required by law.

Regulations on public contracts allow agreements to be entered into without tender for reasons of extreme urgency brought about by unforeseen events. But regulation 50 of the public contracts regulations specifies that a contract award notice (CAN) must be published not later than 30 days after the award of the contract.

The Good Law Project is mounting separate legal challenges over some of the contracts awarded to individuals and companies with links to ministers or officials though a so-called VIP lane. Given the large number of contracts concluded without competition, it argued that the public would have no way of knowing that a contract existed without the publication of a CAN.

The judge also ruled that the government acted unlawfully by failing to comply with its own transparency policy.

The obligations imposed by regulation 50 and the transparency policy "serve a vital public function and that function was no less important during a pandemic," Chamberlain said. "The secretary of state spent vast quantities of public money on pandemic related procurements during 2020 . The public were entitled to see who this money was going to, what it was being spent on, and how the relevant contracts were awarded."

This was important, he said, not only so competitors could understand whether the obligations owed them under the regulations had been breached, but so that oversight bodies such as the National Audit Office, as well as parliament and the public, "could scrutinise and ask questions about this expenditure." He criticised the government for persisting in defending the claim and insisting that it was guilty of only "technical” breaches."

"On receipt of the letter before claim, the sensible course would have been candidly to admit, as the documents now disclosed indicate must have been apparent, that in a substantial number of cases the secretary of state had breached regulation 50, to explain why this had happened, and to undertake to publish the outstanding CANs within a reasonable period," he said.
"If that had been done, this litigation, which by the time of the hearing had cost the secretary of state alone some $€ 207000$ (€239 000, \$290 000), might not have been necessary."

Following the judgment, the Good Law Project wrote to Hancock urging him to publish outstanding contracts and the names of companies who went through the VIP lane. The letter called on him to commit to recovering money from all those who failed to deliver compliant product and undertaking a public inquiry into the handling of PPE procurement.

Jolyon Maugham QC, director of the Good Law Project, said, "We have written to government with a list of proposals in the hope it might work with us to ensure proper governance of these billions in public funds. For too long has government refused to recognise that legitimate public interest. Today's ruling should mark a turning point in government's attitude to these perfectly proper concerns."

A spokeswoman for the Department of Health and Social Care said it had been working tirelessly to deliver protection for health and social care staff, meaning contracts often had to be awarded "at speed." She added, "We fully recognise the importance of transparency in the award of public contracts and continue to publish information about contracts awarded as soon as possible.”

\section{R on the application of Good Law Project Limited and others v Secretary of State for Health and Social Care. 2021 www.bailii.org/ew/cases/EWHC/Ad min/2021/346.html.}

This article is made freely available for use in accordance with BMJ's website terms and conditions for the duration of the covid-19 pandemic or until otherwise determined by BMJ. You may use, download and print the article for any lawful, non-commercial purpose (including text and data mining) provided that all copyright notices and trade marks are retained. 